\title{
PHYSICAL, MECHANICAL AND BIOLOGICAL PROPERTIES OF SESAME PELLETED SEEDS
}

El-Nono, M. A. ${ }^{1}$; A. M. Abdelghany ${ }^{2}$ and E. A. El-Sahhar ${ }^{1}$

1. Agric. Eng. Dept., Fac. of Agric., Ain Shams Univ., Shoubra ElKheima, Cairo, Egypt

2. Corresponding author: Agronomy Dept., Fac. Agric., Ain Shams Univ., Shoubra El-Kheima, P.O. Box 68 Hadayiek Shoubra,11241 Cairo,Egypt,Fax.(202)44444460,Email:dr_ashraf_maher@yahoo.com

\section{ABSTRACT}

Sesame is an important crop for the production of oil especially in newly reclaimed lands of Egypt. A machine for pelleting the small and light sesame seeds was designed and constructed in a laboratory scale to change the shape and size of sesame seeds enlarging the seed by a pellet which more heavier, size and rounder to facilitate sowing sesame seeds by planters. Some of the most important operational parameters were investigated, whereas, rotating speed of the pelleting pan affected the physical pellet properties. Rotating speed of $30 \mathrm{rpm}$ showed the greatest pellet weight, sphericity percentage and true density. Out of three different quantities (100, 250 and $500 \mathrm{~g}$ ) of seeds per run during pelleting process, $250 \mathrm{~g}$ showed maximum pellet axial dimensions, pellet volume and weight. Ratio between pelleting material added to the pan during run and seed quantity was considered, whereas, ratios of $5: 1$, 10:1 and 20:1 were investigated. Maximum pellet axial dimensions and maximum pellet sphericity percentage were obtained when a ratio of 20:1 was applied. The lowest adhesive material concentration (5\%) showed a distinguished pellet size, volume and weight when compared to higher concentration. On the other hand, small quantity of $50 \mathrm{~mm}^{3}$ adhesive solution per $500 \mathrm{~g}$ pelleting material gave maximum pellet volume and weight, however, the maximum quantity of $\left(150 \mathrm{~mm}^{3} / 500 \mathrm{~g}\right.$ pelleting material) gave the greatest sphericity percentage of $76.33 \%$. Ratio of pelleting material components (pentonite / lime) showed that a ratio of $75 \%$ Pentonite: $25 \%$ lime gave maximum pellet dimensions, volume and weight, while a ratio of $0 \%$ Pentonite: $100 \%$ lime showed maximum sphericity percentage. Maximum contact stress and cutting strength decreased with increasing the geometric diameter of the pelleted seeds for all investigated parameters. Both germination and vigor percentages of pelleted seeds were decreased when compared with untreated seeds. Meanwhile, germination rate of pelleted seeds increased when compared with untreated seeds. Therefore, germination and vigor of high quality sesame seeds did not enhanced by pelleting process, while rate of germination remarkably increased when seeds were pelleted perior planting. Pellet dimensions, volume and sphericity are the major variables had a remarkable relation with germination and vigor percentages.

Keywords: Sesame, Sesamum-indicum, Seed, Pelleting, Germination, Vigor.

\section{INTRODUCTION}

In Egypt, sesame is considered one of the most important oil crop and has a great potentiality for human consumption, food, medicine industries and animal feeding. The area of sesame has increased from 26 thousand fed in 1984 to 68 thousand fed in 2005 (Agricultural Statistics, 2006). Generally, pelleting aimed to develop a sensitive sesame seed planting method as an alternative to the traditional broadcast sowing methods. Seed enhancement technology has a central objective to further improve seed performance under 
very specific regimes and with certain planting equipment. While seed pelleting is recommended from the standpoint of seed shape and size, so that it becomes larger, heavier, smoother, more uniform and rounder and thus gives, better flow through the seeding mechanism and minimize the costs of field planting and thinning operation (Copeland and McDonald, 1995), and safety standards for workers, seed protection, seed germination percentage, uniform plant establish and yield (Tilcher, 2005; Halmer, 2005; Abdel-Tawab, 2005 and Shewmaker et al 2002). Small rotating drum coaters are particularly useful for small and light seeds pelleting when it is difficult to use planting machines (Sahhar et al 2006 and Scott et al 1997). However, it was found that coating treatment acted negatively on seed germination when compared to uncoated seeds (Barut and Cagrgan, 2006). On the other hand, pelleted seeds exhibited the highest germination percentage when pelleted seeds were used for field planting in Turkey, while planting pelleted seeds with a pneumatic spacing planter resulted in higher emergence rates and smoother sowing compared with the traditional broadcast sowing method (Dogan et al 2005). Applying growth-promote agent and biocontrol bacteria strains to seed were evaluated for its capacity for biological control and growth promotion. Seed pelleting with such materials was attempted to increase the seed size and to improve the stability and effectiveness of biocontrol capacity (Pyv et al 2006). Same attitude was applied when Trichoderma harzianum was used in coating sesame seed for biocontrol of Macrophomina phaseolina. The pathogen causing charcoal rot in sesame, whereas, significant differences in plant death were observed (Pineda, 2001). Also, three isolates of Trichoderma viride were applied coating to sesame seed to biocontrol Fusarium and Rhizoctonia pathogens (Chung and Choi, 1990). Information on physical, mechanical and biological properties of sesame pelleted seeds is needed for the design of planting machines, also for maintaining high seed quality during pelleting processes. Therefore, the objective of this work is to determine the effect of pelleting process variables on: 1) the physical properties of pelleted seeds (size, shape, volume, sphericity, weight and density); 2) the mechanical properties of pelleted seeds (static coefficient of friction, natural angle of repose, maximum contact stress, cutting strength and pellet hardness), 3) the biological properties (germination and vigor percentages and germination rate) of pelleted seeds processed by pelleting machine, 4) Determining factors that had the most relation with seed quality.

\section{MATERIALS AND METHODS}

\section{Seed material and pelleting machine:}

All pelleting runs were aimed sesame seeds (Shandweel 3) obtained from Oil Crop Research Inst., Agricultural Research Center. This work was accomplished by using an experimental model of seed pelleting machine which designed, manufactured, and operated through a co-operation between Agronomy Dept. and Agric. Eng. Dept., Fac. of Agric., Ain Shams Univ. Full description of the designed machine for seed pelleting (Fig. 1) was demonstrated in detail previously (Sahhar et al 2006). 

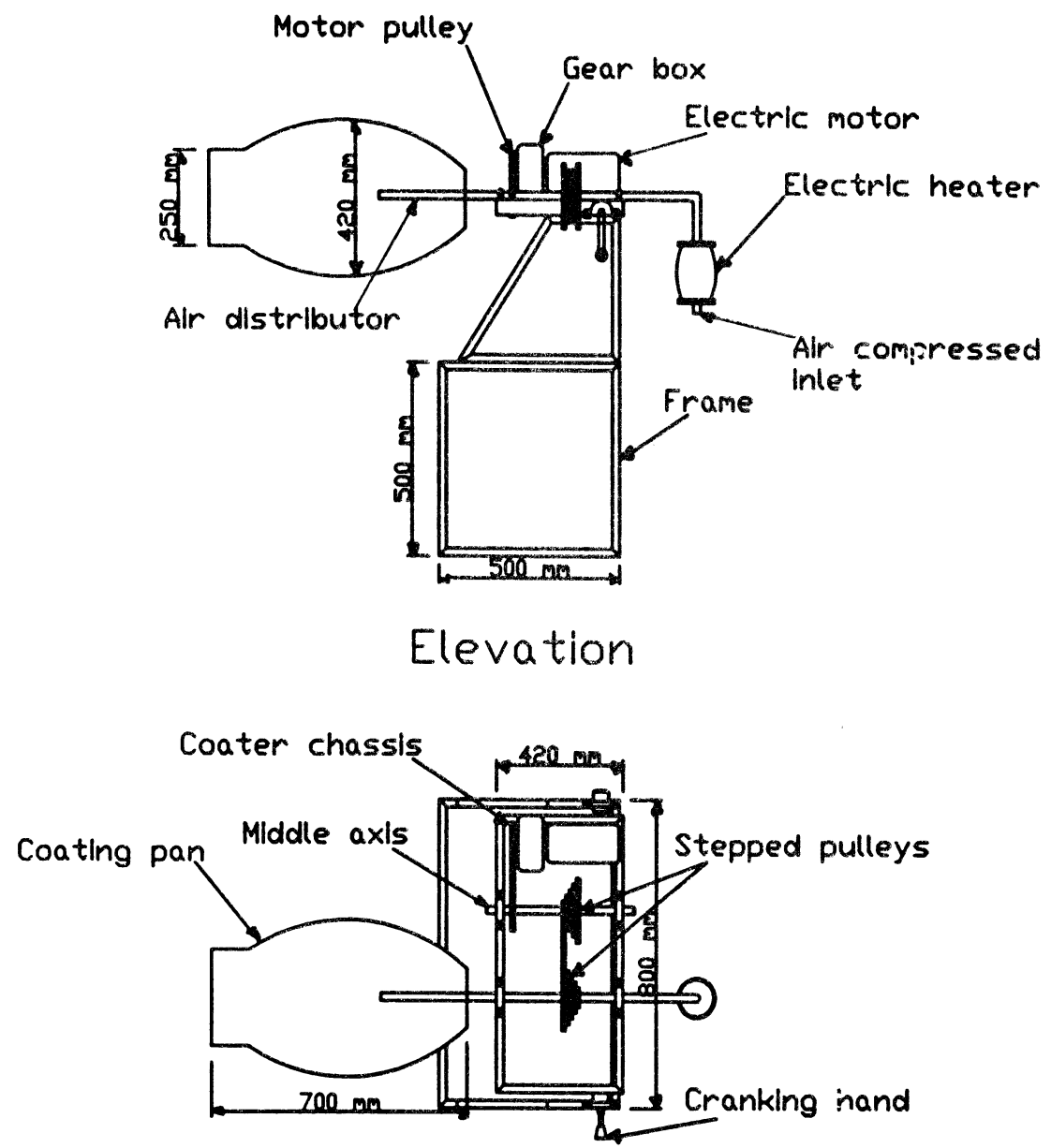

Plan

Fig. 1. The designed seed pelleting machine

\section{Investigation procedure:}

Variables of pelleting process which affect the quality of seed pelleting were investigated by conducting numerous simple experiments. The investigated variables included the rotational speed of the pelleting pan (15, $30,45$ and $60 \mathrm{rpm})$, the quantity of seeds added per run (100, 250 and $500 \mathrm{~g})$ , the ratio of pelleting solid materials to seed $(5,10$ and 20 times), the effect of levels of adhesive concentration (dissolved Arabic gum) (5, 10 and 20\% weight/ volume), the quantity of adhesive solution added per pelleting solids $\left(50,125\right.$ and $150 \mathrm{~mm}^{3} / 500 \mathrm{~g}$ pelleting material), and substituting varying quantities $(0,25,50,75$ and $100 \%)$ of lime (Calcium carbonate) for Pentonite 
(Aluminum silicate) to determine which conditions of pelleting process were most susceptible to the hardness of pelleted seeds.

\section{Investigation conditions:}

As each experiment was conducted, other factors not under investigation were adjusted at $45 \mathrm{rpm}$ for rotating pan speed, $100 \mathrm{~g}$ seed quantity per run, (5:1) pelleting material weight : seed weight, $20 \%$ adhesive concentration, $125 \mathrm{~mm}^{3}$ adhesive quantity/ $500 \mathrm{~g}$ pelleting material, $100 \%$ Pentonite pelleting material, $0.65 \mathrm{~mm}^{3} / \mathrm{S}$ rate of adhesive spraying, $15 \mathrm{~min}$. drying time for produced pellets, $40^{\circ} \mathrm{C}$ air temp. for drying the produced wet pellets and $20^{\circ}$ pan incline angle.

At all levels of different variables, the pelleted seeds were used in these tests after discarding the fine material, unpelleted seeds and agglomerate pelleted seeds which were considered as inert matter.

The main calculations can be summarized as follows:

\section{A) Physical properties of sesame pellets:}

1- Pellet dimensions: the dimensions of the sesame pellets were measured in three directions using a caliper gauge $(0.01 \mathrm{~mm})$. The major diameter was the length of the pellet, the intermediate diameter was the width and the minor diameter was the thickness of the pellet. The minor diameter was taken perpendicular to the intermediate diameter. The caliper was held perpendicular to the direction of the dimension being measured. Dimensions were measured on 100 pellets of four replicates for each treatment:

\section{2- Geometric mean diameter and volume}

The average geometric diameter "Dg" and average volume "V" of pelleted seeds were calculated according to Mohsenin (1986) as follows:

$$
\mathrm{Dg}=(\text { a.b.c })^{1 / 3}, \mathrm{~V}=1 / 6 \Pi a b^{2}
$$

Where: $\mathrm{a}=$ average major diameter in $\mathrm{mm} ; \mathrm{b}=$ average intermediate diameter in $\mathrm{mm}$ and $\mathrm{c}=$ average minor diameter of the raw and pelleted seed in $\mathrm{mm}$.

\section{3- Sphericity:}

The sphericity index, "Sp" was calculated for pelleted seeds according to (Mohsenin, 1986) as follows:

$$
S p=\frac{(a . b . c)^{1 / 3}}{a} \times 100
$$

\section{4- Weight and true density ( unit density):}

The average weight of sesame pellet was recorded and then the true density (unit density) of the pelleted seeds was determined through dividing the average mass of pellet by its average computed volume.

\section{B) Mechanical properties of sesame pellets:}

\section{1- Natural angle of repose}

The natural angle of repose for a pelleted seed sample was measured using a wooden frame full of pelleted seed sample. It was mounted 
on a tilting top drafting table. The table top was tilted until the pellets began to move, leaving an inclined surface. The angle of the inclined pelleted seed surface was measured as the angle of repose for the particular sample " $\phi "$.

\section{2- Static coefficient of friction}

The static friction coefficient " $\mu$ " of pelleted seeds is equal to the tangent of the internal friction of the pellets. A pellet sample of $(100 \mathrm{~g})$ was used to measure the angle " $\alpha$ " at which the pellets sample start to slide down the slope on a tilting steel surface. The following equation was used to calculate the static coefficient of friction: $\mu=\tan \alpha$

\section{3- Maximum contact stress, cutting strength and pellet hardness}

Maximum contact stress "Smax", cutting strength "Scu" and hardness "Hp" of sesame pellets were computed throughout measuring the compressive, cutting and penetrating forces respectively by using (A digital force gauge - Shimpo Model FGC-50-range up to $500 \mathrm{~N}$, Made in Japan) divided by area according to the following equations (ASA E, 1996):

$$
\begin{aligned}
& S_{\text {max }}=\frac{1.5 F_{c o}}{\prod a . b} \\
& S_{c u}=\frac{\boldsymbol{4 F}_{\boldsymbol{c u}}}{\boldsymbol{\Pi} \boldsymbol{D \boldsymbol { g } ^ { 2 }}} \\
& H p=\frac{\mathbf{4 F \boldsymbol { p }}}{\boldsymbol{\Pi} \boldsymbol{d}^{2}}
\end{aligned}
$$

Where: $F_{c o}$ registered compressive force in $\mathbf{N}, \mathbf{F}_{\text {cu }}$ : registered cutting force in $\mathrm{N}$, Fp: registered penetration force in $\mathrm{N}$, Dg: mean geometric diameter of sesame pellet and d: diameter of indentation in $\mathrm{mm}$, a: Semi major axis in $\mathrm{mm}$, b: semi minor axis in $\mathrm{mm}$.

C) Biological properties of sesame pellets:

1- Germination percent of pelleted seeds:

Samples of 100 pellets in four replicates were germinated on rolled towel paper and incubated at $25^{\circ} \mathrm{C}$ for a period of 7-days (ISTA, 1996). Only 2-6 mm pellet size was used in this test, germination percentage "Gp" was calculated as follows:

$$
G p=\frac{\text { No. of germinated pellets }}{\text { Total pellets }} \times 100
$$

\section{2- Vigor percent of pelleted seeds:}

Samples of 100 pellets in four replicates were germinated in coarse sand $\left(3 \mathrm{~cm}\right.$ depth) and incubated at $25^{\circ} \mathrm{C}$ for a period of 7 -days (ISTA, 1996). Only 2-6 mm pellet size was used in this test, vigor percentage "Vp" was calculated as follows: 
El-Nono, M. A. et al.

$$
V p=\frac{\text { No. of germinated pellets }}{\text { Total pellets }} \times 100
$$

\section{3- Germination rate of pelleted seeds:}

Germination rate $(\mathrm{Gr})$ were calculated by counting number of seedlings emerged during germination period after 4 days from planting up to four counts (2days intervals) (ISTA, 1996).

$$
G r=\frac{a+(a+b)+(a+b+c)+\ldots}{n(a+b+c+\ldots)}
$$

Where: $a=$ first count of germinated seed, $b=$ second count, $c=$ third count Statistical analysis

$$
\text { and } n=\text { number of counts }
$$

Treatments were accomplished according to complete random design in four replicates. The data were analyzed according to (SAS, 1988). Means were compared using least significant difference (LSD 5\%), also backward multiple regression analysis was performed according to (Gomez and Gomez, 1984).

\section{RESULTS AND DISCUSSION}

\section{Effect of rotational speed of pelleting pan on some physical properties of sesame pelleted seeds}

Data presented in Table (1) indicate that pelleted seed dimension varied significantly as response to pan rotational speed except major diameter, consequently, pellet volume varied approx. from 19.89-28.88 $\mathrm{mm}^{3}$. It was found that the major dimension of pellet (where the length of the seed within the pellet was at that position showed the longest dimension) varied from $4.14 \mathrm{~mm}$ to $4.38 \mathrm{~mm}$. Intermediate length (where the width of the seed within the pellet was at that position) varied from $2.87 \mathrm{~mm}$ to $3.57 \mathrm{~mm}$. Meanwhile, minor dimension (where the thickness of the seed within the pellet was at that position) varied from $1.88 \mathrm{~mm}$ to $3.07 \mathrm{~mm}$. It is noticeable that the three dimensions were lowest when $60 \mathrm{rpm}$ was applied; on the other hand, the greatest values of the three dimensions were obtained when 30 rpm of rotational pan speed was applied during pelleting process. Speeds of 15 and $45 \mathrm{rpm}$ gave in between values for the three dimensions. Seed volume before pelleting process (raw seed) measured $7.52 \mathrm{~mm}^{3}$, while this volume enlarged to $19.89 \mathrm{~mm}^{3}$ and $28.88 \mathrm{~mm}^{3}$, when 60 and $30 \mathrm{rpm}$ of rotational pan were applied, respectively. High speed of pelleting pan up to $60 \mathrm{rpm}$ produced the smallest pellet volume. Since the aim of the study is to change the sesame seed dimensions which are small in measure and elliptical in shape, results obtained indicate that pelleting process caused seed length to change from a dimension of $3.50 \mathrm{~mm}$ to $4.38 \mathrm{~mm}$, seed width enlarge from $2.03 \mathrm{~mm}$ to $3.57 \mathrm{~mm}$ and seed thickness enlarged from 0.90 $\mathrm{mm}$ to $3.07 \mathrm{~mm}$. These enlargements in seed dimensions reached percentages, of $25.14,75.88$ and 241.11 for sesame seed length, width and 
thickness respectively. Results indicate that placing sesame seed in a pellet almost round was achieved, however, if the roundness of the produced pellet is not enough, causing problems during mechanical planting, a device for chafe seed against emery surface will be recommended to be attached or followed the pelleting machine. Trying to achieve a more roundness pellet by enlarging the pellet size is not preferable under the present investigation conditions.

Table 1. Effect of rotational speed of pelleting pan on some physical properties of sesame pelleted seeds.

\begin{tabular}{|c|c|c|c|c|c|c|c|c|}
\hline \multirow{2}{*}{$\begin{array}{l}\text { Pan rotational } \\
\text { speed (rpm) }\end{array}$} & \multicolumn{3}{|c|}{ Seed axial dimensions, $\mathrm{mm}$} & \multirow{2}{*}{$\begin{array}{c}\text { Geometric } \\
\text { diameter } \\
\text { mm }\end{array}$} & \multirow{2}{*}{$\begin{array}{c}\text { Volume } \\
\mathrm{mm}^{3}\end{array}$} & \multirow{2}{*}{$\begin{array}{c}\text { Sphericity } \\
\%\end{array}$} & \multirow{2}{*}{$\begin{array}{c}\text { Weight } \\
\text { mg }\end{array}$} & \multirow{2}{*}{$\begin{array}{c}\text { True } \\
\text { density } \\
\mathrm{mg} / \mathrm{mm}^{3}\end{array}$} \\
\hline & Major & $\begin{array}{c}\text { Inter- } \\
\text { mediate }\end{array}$ & Minor & & & & & \\
\hline $\begin{array}{l}\text { Untreated } \\
\text { seed }\end{array}$ & 3.50 & 2.03 & 0.90 & 1.85 & 7.52 & 52.90 & 0.032 & 0.044 \\
\hline 15 & 4.32 & 3.28 & 2.92 & 3.43 & 25.04 & 80.09 & 29.63 & 1.164 \\
\hline 30 & 4.26 & 3.57 & 3.07 & 3.59 & 28.88 & 84.48 & 62.56 & 2.039 \\
\hline 45 & 4.38 & 3.08 & 2.52 & 3.21 & 23.65 & 79.63 & 37.32 & 1.558 \\
\hline 60 & 4.14 & 2.87 & 1.88 & 2.78 & 19.89 & 66.40 & 10.55 & 0.454 \\
\hline LSD at $50 \%$ & N.S & 0.82 & 0.80 & 0.81 & N.S & 6.79 & 31.55 & 0.56 \\
\hline
\end{tabular}

As seed pellet increased in its dimensions and accordingly the calculated volume, it was found that seed sphericity percentage increased in turn. Meaning that, increasing pellet dimensions increased pellet size and sphericity percentage (pellet become more round). Pellet produced at $30 \mathrm{rpm}$ pan speed showed the maximum sphericity percentage. Although, applying $30 \mathrm{rpm}$ pan speed gave the maximum sphericity percentage, it did not show superiority over the other two pan speed (15 and $45 \mathrm{rpm}$ ) since differences did not reach significance level. Applying speed of $30 \mathrm{rpm}$ for pelleting pan gave the maximum pellet size; consequently, the produced pellet gave maximum weight of $(62.56 \mathrm{mg})$. Accordingly true density $\mathrm{mg} / \mathrm{mm}^{3}$ of such pellet showed maximum value of $\left(2.039 \mathrm{~g} / \mathrm{mm}^{3}\right)$. The characteristics of the pellet produced under pan speed of $30 \mathrm{rpm}$ showed the most promising and probable values.

\section{Effect of seed quantity per run on some physical properties of sesame pelleted seeds}

Different seed quantities were selected to investigate the machine response and properties of the produced pellets, data were tabulated in Table (2). Results show that increasing amount of seed per run up to $250 \mathrm{~g}$ increased the measured pellet dimensions to the values of $4.62 \mathrm{~mm}$ for major dimension, $3.45 \mathrm{~mm}$ for intermediate dimension and $2.94 \mathrm{~mm}$ for minor dimension. Ratio between pan size and amount of seeds to be placed in is one of the most important factor affecting the success of pelleting process. It is clear that all data obtained of both amounts of 100 and $250 \mathrm{~g}$ per run did not differ significantly, while, using amount of $250 \mathrm{~g}$ per run showed no significant increase upon amount of 100 and $500 \mathrm{~g}$ in all studied characters documented in (Table2). 
Table 2. Effect of seed quantity per run on some properties of sesame physical pelleted seeds.

\begin{tabular}{|c|c|c|c|c|c|c|c|c|}
\hline \multirow[b]{2}{*}{$\begin{array}{l}\text { Seed quantity } \\
\text { (g/ run) }\end{array}$} & \multicolumn{3}{|c|}{ Seed axial dimensions, $\mathrm{mm}$} & \multirow{2}{*}{$\begin{array}{c}\text { Geometric } \\
\text { diameter } \\
\mathrm{mm}\end{array}$} & \multirow[b]{2}{*}{$\begin{array}{l}\text { Volume } \\
\text { mm }^{3}\end{array}$} & \multirow[b]{2}{*}{$\begin{array}{c}\text { Sphericity } \\
\%\end{array}$} & \multirow[b]{2}{*}{$\begin{array}{l}\text { Weight } \\
\text { mg }\end{array}$} & \multirow{2}{*}{$\begin{array}{c}\text { True } \\
\text { density } \\
\mathrm{mg} / \mathrm{mm}^{3}\end{array}$} \\
\hline & Major & $\begin{array}{l}\text { Inter- } \\
\text { mediate }\end{array}$ & Minor & & & & & \\
\hline $\begin{array}{l}\text { Untreated } \\
\text { seed }\end{array}$ & 3.50 & 2.03 & 0.90 & 1.85 & 7.52 & 52.90 & 0.32 & 0.044 \\
\hline $\begin{array}{l}100 \mathrm{~g} \\
250 \mathrm{~g} \\
500 \mathrm{~g}\end{array}$ & $\begin{array}{l}4.37 \\
4.62 \\
4.31\end{array}$ & $\begin{array}{l}3.07 \\
3.45 \\
3.16\end{array}$ & $\begin{array}{l}2.47 \\
2.94 \\
2.76\end{array}$ & $\begin{array}{l}3.15 \\
3.58 \\
3.32\end{array}$ & $\begin{array}{l}23.51 \\
30.50 \\
23.85\end{array}$ & $\begin{array}{l}72.80 \\
77.50 \\
78.24\end{array}$ & $\begin{array}{l}42.24 \\
91.05 \\
75.68\end{array}$ & $\begin{array}{l}2.286 \\
3.170 \\
3.374\end{array}$ \\
\hline LSD at $50 \%$ & N.S. & 0.91 & 0.90 & 0.94 & N.S & 7.63 & 35.95 & 1.11 \\
\hline
\end{tabular}

It is clear that average pellet volume of $23.51,30.50$ and $23.85 \mathrm{~mm}^{3}$, and average sphericity percentage of $72.8,77.5$ and $78.24 \%$ were obtained when the amount of feeding were 100,250 and $500 \mathrm{~g}$ seeds / run , respectively. Also it showed that the quantity of $250 \mathrm{~g} /$ run gave the biggest pellet volume $\left(30.50 \mathrm{~mm}^{3}\right)$ and weight $(91.05 \mathrm{mg})$, but a quantity of $500 \mathrm{~g}$ seeds/ run gave maximum sphericity percentage (78.245) and true density $\left(3.374 \mathrm{mg} / \mathrm{mm}^{3}\right.$ ). It could be concluded that amount of $250 \mathrm{~g}$ seeds/ run showed promising characteristics of physical properties suitable for the aim of this study.

\section{Effect of ratio of pelleting material: Seed quantity on some physical properties:}

Data presented in Table (3) show pellet dimensions were affected significantly by ratio of pelleting material weight used in pelleting process to seed weight. The ratios used were 5:1, 10:1 and 20:1, whereas, maximum dimensions were obtained when ratio of 20:1 was applied giving values of $4.58,3.93$ and $3.31 \mathrm{~mm}$ for major, intermediate and minor dimensions respectively, but ratios of 5:1 or 10:1 produced smaller pellets. Such finding may be due to increasing pelleting material in the pan during process which allow enough pelleting material to reach seed and producing bigger pellet size. Accordingly, geometric diameter and volume showed the maximum values in seeds pelleted at a ratio of $20: 1$ their values were $3.88 \mathrm{~mm}$ and $38.86 \mathrm{~mm}^{3}$, respectively. However, sphericity percentage of pellets produced at a ratio 5: 1 showed less value meaning that, when pelleting material used was five fold the amount of seed, the produced pellets were less round. Pellet produced with a pelleting material 20 fold seed weight formed the heaviest pellet $(109.08 \mathrm{mg})$, such pellet showed maximum true density $\left(3.235 \mathrm{mg} / \mathrm{mm}^{3}\right)$.

\section{Effect of adhesive concentration on some physical properties of sesame pelleted seeds}

Data presented in (Table 4) demonstrate the effect of adhesive concentration on pelleting process, whereas, significant effects of adhesive concentration were found in all studied characters. Increasing adhesive material (Arabic gum) up to 10 and $20 \%$ did not affect significantly producing pellets with more favorable characteristics. However, pellets produced by using solution of 5 and $10 \%$ adhesive concentration gave biggest pellet volume of 32.93 and $31.79 \mathrm{~mm}^{3}$ respectively. On the other hand, more 
adhesive concentration (20\%) produced pellets with smaller volume 22.64 $\mathrm{mm}^{3}$. Significant differences were found in sphericity percentage, pellet weight and true density in the three different adhesive concentration used in producing pellets whereas, applying $5 \%$ adhesive solution produced pellet with maximum values of $81.53 \%, 107.61 \mathrm{mg}$ and $3.462 \mathrm{mg} / \mathrm{mm}^{3}$, respectively. Therefore, it is concluded that physical properties of pellets affected by concentration of adhesive solution.

Table 3. Effect of ratio of pelleting material to seed quantity on some physical properties of sesame pelleted seeds.

\begin{tabular}{|c|c|c|c|c|c|c|c|c|}
\hline \multirow{2}{*}{$\begin{array}{c}\text { Pelleting } \\
\text { material : seed } \\
\text { quantity }\end{array}$} & \multicolumn{3}{|c|}{ Seed axial dimensions, $\mathrm{mm}$} & \multirow{2}{*}{$\begin{array}{c}\text { Geometric } \\
\text { diameter } \\
\text { mm }\end{array}$} & \multirow[b]{2}{*}{$\begin{array}{c}\text { Volume } \\
\mathrm{mm}^{3}\end{array}$} & \multirow[b]{2}{*}{$\begin{array}{c}\text { Sphericity } \\
\%\end{array}$} & \multirow[b]{2}{*}{$\begin{array}{l}\text { Weight } \\
\text { mg }\end{array}$} & \multirow{2}{*}{$\begin{array}{c}\text { True } \\
\text { density } \\
\mathrm{mg} / \mathrm{mm}^{3}\end{array}$} \\
\hline & Major & $\begin{array}{c}\text { Inter- } \\
\text { mediate }\end{array}$ & Minor & & & & & \\
\hline $\begin{array}{l}\text { Untreated } \\
\text { seed }\end{array}$ & 3.50 & 2.03 & 0.90 & 1.85 & 7.52 & 52.90 & 0.032 & 0.044 \\
\hline $5: 1$ & 4.20 & 2.97 & 2.50 & 3.18 & 20.51 & 72.87 & 40.77 & 2.434 \\
\hline $10: 1$ & 4.66 & 3.71 & 3.02 & 3.73 & 35.02 & 80.61 & 53.44 & 1.828 \\
\hline $20: 1$ & 4.58 & 3.93 & 3.31 & 3.88 & 38.86 & 85.17 & 109.08 & 3.235 \\
\hline LSD at $50 \%$ & N.S & 0.86 & 0.79 & 0.87 & 19.96 & 5.72 & 17.42 & 1.59 \\
\hline
\end{tabular}

Table 4. Effect of adhesive solution concentration on some physical properties of sesame pelleted seeds.

\begin{tabular}{|c|c|c|c|c|c|c|c|c|}
\hline \multirow[b]{2}{*}{$\begin{array}{c}\text { Adhesive } \\
\text { solution conc. }\end{array}$} & \multicolumn{3}{|c|}{ Seed axial dimensions, $\mathrm{mm}$} & \multirow{2}{*}{$\begin{array}{c}\text { Geometric } \\
\text { diameter } \\
\text { mm }\end{array}$} & \multirow[b]{2}{*}{$\begin{array}{c}\text { Volume } \\
\text { mm }^{3}\end{array}$} & \multirow[b]{2}{*}{$\begin{array}{c}\text { Sphericity } \\
\%\end{array}$} & \multirow[b]{2}{*}{$\begin{array}{c}\text { Weight } \\
\text { mg }\end{array}$} & \multirow{2}{*}{$\begin{array}{c}\text { True } \\
\text { density } \\
\mathrm{mg} / \mathbf{m m}^{3}\end{array}$} \\
\hline & Major & $\begin{array}{c}\text { Inter- } \\
\text { mediate }\end{array}$ & Minor & & & & & \\
\hline $\begin{array}{l}\text { Untreated } \\
\text { seed }\end{array}$ & 3.50 & 2.03 & 0.90 & 1.85 & 7.52 & 52.90 & 0.032 & 0.044 \\
\hline $5 \%$ & 4.59 & 3.67 & 3.14 & 3.73 & 32.93 & 81.53 & 107.61 & 3.462 \\
\hline $10 \%$. & 4.54 & 3.60 & 2.81 & 3.56 & 31.79 & 78.33 & 82.02 & 2.894 \\
\hline $20 \%$ & 4.25 & 3.07 & 2.52 & 3.18 & 22.64 & 71.86 & 54.78 & 3.076 \\
\hline LSD at $50 \%$ & 0.59 & 0.83 & 0.91 & 0.81 & 16.36 & 7.87 & 17.68 & 1.74 \\
\hline
\end{tabular}

Effect of quantity of adhesive solution on some physical properties of sesame pelleted seeds

Quantity of adhesive solutions was considered as one of the most important factor affecting the pelleting process. These different quantities of solution were 50,125 and $150 \mathrm{~mm}^{3} / 500 \mathrm{~g}$ pelleting material. Results in Table (5) indicate that applying amount of $50 \mathrm{~mm}^{3} / 500 \mathrm{~g}$ pelleting material gave considerable pellet dimensions of $4.51,3.41$ and $2.50 \mathrm{~mm}$ for the three dimensions major, intermediate and minor diameters, respectively. While pellets produced by applying both 125 and $150 \mathrm{~mm}^{3} / 500 \mathrm{~g}$ pelleting material gave close dimensions to that of the smaller amount used. Therefore, it could be concluded that increasing amount of adhesive solution had no significant effect on increasing dimension, geometric diameter and pellet volume. Meanwhile, sphericity percentage reached the maximum $(74.19 \%)$ when $50 \mathrm{~mm}^{3}$ was used to produce sesame pellets. Therefore such amount of adhesive solution produced more round pellets. Moreover, applying amount of adhesive solution of $50 \mathrm{~mm}^{3} / 500 \mathrm{~g}$ pelleting material produced heavier pellets $(119.57 \mathrm{mg})$, the true density of such pellets was $5.362 \mathrm{mg} / \mathrm{mm}^{3}$. Therefore, applying amount of $50 \mathrm{~mm}^{3} / 500 \mathrm{~g}$ pelleting material produced pellets with pronounced characteristics. 
Table 5. Effect of volume of adhesive solution to pelleting material (filler) on some physical properties of sesame pelleted seeds.

\begin{tabular}{|c|c|c|c|c|c|c|c|c|}
\hline \multirow[b]{2}{*}{$\begin{array}{l}\text { Volume } \\
\text { adhesive } \\
\text { solution/ } \\
\text { weight }\end{array}$} & \multicolumn{3}{|c|}{ Seed axial dimensions, $\mathrm{mm}$} & \multirow[b]{2}{*}{$\begin{array}{c}\text { Geometric } \\
\text { diameter } \\
\text { mm }\end{array}$} & \multirow[b]{2}{*}{$\begin{array}{c}\text { Volume } \\
\mathrm{mm}^{3}\end{array}$} & \multirow[b]{2}{*}{$\begin{array}{c}\text { Sphericity } \\
\%\end{array}$} & \multirow[b]{2}{*}{$\begin{array}{l}\text { Weight } \\
\text { mg }\end{array}$} & \multirow[b]{2}{*}{$\begin{array}{c}\text { True } \\
\text { density } \\
\mathrm{mg} / \mathrm{mm}^{3}\end{array}$} \\
\hline & Major & $\begin{array}{c}\text { Inter- } \\
\text { mediate }\end{array}$ & Minor & & & & & \\
\hline $\begin{array}{l}\text { Untreated } \\
\text { seed }\end{array}$ & 3.50 & 2.03 & 0.90 & 1.85 & 7.52 & 52.90 & 0.032 & 0.044 \\
\hline $50 \mathrm{~mm}^{3} / 500 \mathrm{~g}$ & 4.51 & 3.41 & 2.50 & 3.35 & 29.79 & 74.19 & 119.57 & 5.362 \\
\hline $125 \mathrm{~mm}^{3} / 500 \mathrm{~g}$ & 4.35 & 3.06 & 2.55 & 3.13 & 23.29 & 72.88 & 65.85 & 4.126 \\
\hline $150 \mathrm{~mm}^{3} / 500 \mathrm{~g}$ & 4.47 & 3.34 & 2.72 & 3.11 & 26.99 & 76.33 & 44.17 & 1.842 \\
\hline LSD at $50 \%$ & N.S & 0.93 & 0.91 & 0.90 & N.S & 8.38 & N.S & 3.42 \\
\hline
\end{tabular}

Effect of pelleting material composition on some physical properties of sesame pelleted seeds

Data presented in Table (6) show the ratio of both Pentonite and lime used in pelleting material, whereas, maximum pellet dimension varied according to the ratio of elements of pelleting material. The maximum major dimension was produced when a ratio of ( $25 \%$ pentonite $+75 \%$ lime) was used giving a value of $4.74 \mathrm{~mm}$, maximum intermediate dimension $(3.93 \mathrm{~mm})$ was achieved when a ratio of ( $100 \%$ pentonite +0 lime) was used, and maximum minor dimension of pellets $(3.02 \mathrm{~mm})$ was produced when a ratio of $(75 \%$ pentonite $+25 \%$ lime) was used, which also produced maximum geometric diameter $(3.71 \mathrm{~mm})$ and maximum volume $\left(34.95 \mathrm{~mm}^{3}\right)$. Moreover, such treatment produced more round pellet since sphericity percentage recorded a maximum value of $79.25 \%$, the weight of such pellet reached $119.84 \mathrm{mg}$., true density gave a value of $4.063 \mathrm{mg} / \mathrm{mm}^{3}$. Although the three dimension varied between treatments, pellet produced by using material of ( $75 \%$ pentonite $+25 \%$ lime) gave pronouncing characteristics of volume and sphericity percentage.

Table 6. Effect of Pentonite: Lime ratio used in pelleting material on some physical properties of sesame pelleted seeds.

\begin{tabular}{|c|c|c|c|c|c|c|c|c|}
\hline \multirow[b]{2}{*}{$\begin{array}{l}\text { Pentonite: } \\
\text { lime ratio }\end{array}$} & \multicolumn{3}{|c|}{ Seed axial dimensions, $\mathrm{mm}$} & \multirow{2}{*}{$\begin{array}{c}\text { Geometric } \\
\text { diameter } \\
\text { mm }\end{array}$} & \multirow[b]{2}{*}{$\begin{array}{c}\text { Volume } \\
\text { mm }^{3}\end{array}$} & \multirow[b]{2}{*}{$\begin{array}{c}\text { Sphericity } \\
\%\end{array}$} & \multirow[b]{2}{*}{$\begin{array}{c}\text { Weight } \\
\text { mg }\end{array}$} & \multirow{2}{*}{$\begin{array}{c}\text { True } \\
\text { density } \\
\mathrm{mg} / \mathrm{mm}^{3}\end{array}$} \\
\hline & Major & $\begin{array}{c}\text { Inter- } \\
\text { mediate }\end{array}$ & Minor & & & & & \\
\hline Untreated seed & 3.50 & 2.03 & 0.90 & 1.85 & 7.52 & 52.90 & 0.032 & 0.044 \\
\hline $100 \%$ Pentonite & 4.28 & 3.93 & 2.43 & 3.16 & 21.04 & 72.86 & 56.77 & 3.858 \\
\hline $\begin{array}{l}25 \% \text { pent: } 75 \% \\
\text { lime }\end{array}$ & 4.74 & 3.62 & 2.97 & 3.68 & 34.30 & 77.90 & 87.29 & 3.093 \\
\hline $\begin{array}{l}50 \% \text { pent: } 50 \% \\
\text { lime }\end{array}$ & 4.64 & 3.41 & 2.84 & 3.54 & 30.09 & 76.16 & 114.69 & 4.801 \\
\hline $\begin{array}{l}75 \% \text { pent.: } 25 \% \\
\text { lime }\end{array}$ & 4.69 & 3.68 & 3.02 & 3.71 & 34.95 & 79.25 & 119.84 & 4.063 \\
\hline $100 \%$ lime & 4.41 & 3.47 & 2.86 & 3.51 & 29.47 & 79.40 & 107.28 & 4.533 \\
\hline LSD at $5 \%$ & 0.83 & 0.96 & 0.92 & 0.86 & N.S & 7.87 & 11.16 & 3.089 \\
\hline
\end{tabular}

Effect of pelleting parameters on some mechanical properties of sesame pelleted seeds:

Since angle of repose of seeds is depended on the pellet shape, size and dimensions, such character must be considered in designing machines that handle and planting the pelleted seeds. However, data obtained show no significant differences due to all treatments under investigation (Tables 7-12). 
Also, coefficient of friction was considered in the present investigation since such factor is related to mechanical motion of pellets on metal surface especially planters revealing a pellet character responsible for facilitating pellet flow in planters. Rotational pan speed of $45 \mathrm{rpm}$ showed less coefficient of friction (0.713) of produced pellets (Table 7) when compared to other pelleted seeds. Using $250 \mathrm{~g}$ seed/ run showed less coefficient friction (0.726) compared to the other seed quantity exposed to the pelleting process (Table 8). Meanwhile, applying fillers at ratio of 5 times the seed in pelleting pan, using $10 \%$ adhesive concentration, using $125 \mathrm{~mm}^{3}$ adhesive solution / $500 \mathrm{~g}$ pelleting material and $100 \%$ Pentonite gave coefficient of friction values of $0.675,0.589,0.694$ and 0.694 , respectively (Tables $9-12$ ).

Figures 2, 3 and 4 show the effect of pelleting parameters on the max. contact stress, cutting strength and the pellet hardness. It is clear that max. contact stress and cutting strength decreased with increasing the geometric diameter of the pelleted seeds for the parameters that were used. This could be due to the decrease in the unit density. However, pellet hardness increased with increasing the geometric diameter of the pelleted seeds for the parameters that were used. This may be due to the effect of adhesive solution and the applied heat during process.

\section{Effect of pelleting parameters on some biological properties of sesame seeds}

Data presented in Tables (7-12) show response of some biological properties (Germination and vigor percentages and germination rate) to the selected investigated parameters affecting pelleting process of sesame seed. It was previously reported that pelleting increased germination rate, more uniform emergence, germination under a boarder range of environments, and improved seedling vigor and growth (Copeland and McDonald, 1995). Pelleting sesame seeds was found to reduce germination percentage and vigor percentage at all levels of studied parameters when pelleted seed compared to untreated seeds. Pelleting process required to hydrate seeds with adhesive solution and re-drying the pellets which contained seed again. Also, using some filler to form a pellet and cementing additives (Arabic gum) may hinders the germination causing a slight reduction of percentage. However, surrounding the seed with a pellet to improve precision planting and facilitate the free flow of these seeds in planters may overcome the reduction occurred in germination percentage. Because pelleting material is wet during process so that inadvertent seed hydration occurs, this leads to increase respiration and possibly reduced seed quality. In other instance, if the pelleting material is too hard after drying, it may be difficult for radical emergence through the pellet material. Therefore, such technical problems must be monitored during pelleting process so that seed quality is maintained and germination is not hindered. Maximum germination percentages of pelleted seeds were obtained when $60 \mathrm{rpm}$ drum speed, $100 \mathrm{~g}$ seed / run, ratio of fillers was 5 times the seed weight (5:1), $20 \%$ adhesive concentration and ratio of $100 \%$ Pentonite : $0 \%$ lime filling material were used. Maximum Vigor percentage of pelleted seeds recorded when $45 \mathrm{rpm}$ drum speed, $100 \mathrm{~g}$ seed/ run, (5:1) ratio of fillers weight: seed weight, $5 \%$ adhesive 
El-Nono, M. A. et al.

concentration, and ratio of $100 \%$ Pentonite: $0 \%$ lime filling material were applied. Compared to raw seed (untreated seed), pelleted seeds were superior in germination rate, whereas, maximum values were obtained as speed of $60 \mathrm{rpm}$ for the drum, $100 \mathrm{~g}$ seed/ run, ratio of fillers was 10 times the seed weight $(10: 1), 5 \%$ adhesive concentration and ratio of $100 \%$ Pentonite: $0 \%$ lime filling material were used.

Table 7. Effect of rotational speed of pelleting pan on some mechanical and biological properties of sesame pelleted seeds.

\begin{tabular}{|lccccc|}
\hline $\begin{array}{c}\text { Pan rotational } \\
\text { speed (rpm) }\end{array}$ & $\begin{array}{c}\text { Angle of } \\
\text { repose } \\
\text { deg. }\end{array}$ & $\begin{array}{c}\text { Coefficient Germination } \\
\text { friction }\end{array}$ & $\begin{array}{c}\text { Vigor } \\
\text { percentage }\end{array}$ & $\begin{array}{c}\text { Germination } \\
\text { percentage }\end{array}$ & \\
\hline rate
\end{tabular}

Table 8. Effect of seed amount per run on some mechanical and biological properties of sesame pelleted seeds.

\begin{tabular}{|lccccc|}
\hline $\begin{array}{c}\text { Seed quantity } \\
\text { (g)/ run }\end{array}$ & $\begin{array}{c}\text { Angle of } \\
\text { repose } \\
\text { deg. }\end{array}$ & $\begin{array}{c}\text { Coefficient } \\
\text { friction }\end{array}$ & $\begin{array}{c}\text { Germination } \\
\text { percentage }\end{array}$ & $\begin{array}{c}\text { Vigor } \\
\text { percentage }\end{array}$ & $\begin{array}{c}\text { Germination } \\
\text { rate }\end{array}$ \\
\hline Untreated seed & 17.00 & 0.675 & 88.50 & 80.25 & 0.73 \\
$100 \mathrm{~g}$. & 14.00 & 0.754 & 71.50 & 65.50 & 0.93 \\
$250 \mathrm{~g}$. & 16.00 & 0.727 & 70.25 & 61.00 & 0.88 \\
$500 \mathrm{~g}$. & 17.25 & 1.018 & 70.25 & 62.00 & 0.76 \\
\hline LSD at $50 \%$ & $\mathrm{~N} . \mathrm{S}$ & 0.103 & 6.09 & 5.22 & 0.08 \\
\hline
\end{tabular}

Table 9. Effect of ratio of pelleting material to seed quantity on some mechanical and biological properties of sesame pelleted seeds.

\begin{tabular}{|lccccc|}
\hline $\begin{array}{l}\text { Pelleting material : } \\
\text { seed quantity }\end{array}$ & $\begin{array}{c}\text { Angle } \\
\text { of } \\
\text { repose } \\
\text { deg. }\end{array}$ & $\begin{array}{c}\text { Coefficient } \\
\text { friction }\end{array}$ & $\begin{array}{c}\text { Germination } \\
\text { percentage }\end{array}$ & $\begin{array}{c}\text { Vigor } \\
\text { percentage }\end{array}$ & $\begin{array}{c}\text { Germination } \\
\text { rate }\end{array}$ \\
\hline Untreated seed & 17.00 & 0.675 & 88.50 & 80.25 & 0.73 \\
$5: 1$ & 14.25 & 0.675 & 72.25 & 60.50 & 0.90 \\
$10: 1$ & 16.00 & 1.268 & 65.00 & 59.75 & 0.91 \\
$20: 1$ & 17.25 & 0.974 & 65.00 & 60.00 & 0.85 \\
\hline LSD at $50 \%$ & N.S & 0.095 & 7.93 & 2.54 & 0.06 \\
\hline
\end{tabular}


Table 10. Effect of adhesive solution concentration on some mechanical and biological properties of sesame pelleted seeds.

\begin{tabular}{|lccccc|}
\hline $\begin{array}{c}\text { Adhesive } \\
\text { solution } \\
\text { concentration }\end{array}$ & $\begin{array}{c}\text { Angle of } \\
\text { repose } \\
\text { deg. }\end{array}$ & $\begin{array}{c}\text { Coefficient } \\
\text { friction }\end{array}$ & $\begin{array}{c}\text { Germination } \\
\text { percentage }\end{array}$ & $\begin{array}{c}\text { Vigor } \\
\text { percentage }\end{array}$ & $\begin{array}{c}\text { Germination } \\
\text { rate }\end{array}$ \\
\hline Untreated seed & 17.00 & 0.675 & 88.50 & 80.25 & 0.73 \\
$5 \%$ & 15.00 & 0.747 & 67.25 & 61.75 & 0.91 \\
$10 \%$ & 15.50 & 0.589 & 63.00 & 59.50 & 0.82 \\
$20 \%$ & 13.75 & 0.687 & 71.25 & 59.75 & 0.85 \\
\hline LSD at $50 \%$ & $\mathrm{~N} . \mathrm{S}$ & 0.072 & 8.69 & 3.25 & 0.07 \\
\hline
\end{tabular}

Table 11. Effect of volume of adhesive solution to seed quantity on some mechanical and biological properties of sesame pelleted seeds.

\begin{tabular}{|lccccc|}
\hline $\begin{array}{l}\text { Volume of } \\
\text { adhesive } \\
\text { solution : seed } \\
\text { weight }\end{array}$ & $\begin{array}{c}\text { Angle of } \\
\text { repose } \\
\text { deg. }\end{array}$ & $\begin{array}{c}\text { Coefficient } \\
\text { friction }\end{array}$ & $\begin{array}{c}\text { Germination } \\
\text { percentage }\end{array}$ & $\begin{array}{c}\text { Vigor } \\
\text { percentage }\end{array}$ & $\begin{array}{c}\text { Germination } \\
\text { rate }\end{array}$ \\
\hline Untreated seed & 17.00 & 0.675 & 88.50 & 80.25 & 0.73 \\
$50 \mathrm{~mm}^{3} / 500 \mathrm{~g}$ & 13.50 & 1.235 & 71.75 & 60.25 & 0.90 \\
$125 \mathrm{~mm}^{3} / 500 \mathrm{~g}$ & 14.00 & 0.694 & 71.50 & 59.75 & 0.87 \\
$150 \mathrm{~mm}^{3} / 500 \mathrm{~g}$ & 14.50 & 1.224 & 70.25 & 59.50 & 0.82 \\
\hline LSD at $50 \%$ & $\mathrm{~N} . \mathrm{S}$ & 0.252 & 4.86 & 3.37 & 0.08 \\
\hline
\end{tabular}

Table 12. Effect of Pentonite: lime ratio used in pelleting material on some mechanical and biological properties of sesame pelleted seeds.

\begin{tabular}{|c|c|c|c|c|c|}
\hline $\begin{array}{l}\text { Pentonite : lime } \\
\text { ratio }\end{array}$ & $\begin{array}{l}\text { Angle of } \\
\text { repose } \\
\text { deg. }\end{array}$ & $\begin{array}{l}\text { Coefficient } \\
\text { friction }\end{array}$ & $\begin{array}{l}\text { Germination } \\
\text { percentage }\end{array}$ & $\begin{array}{c}\text { Vigor } \\
\text { percentage }\end{array}$ & $\begin{array}{l}\text { Germination } \\
\text { rate }\end{array}$ \\
\hline Untreated seed & 17.00 & 0.675 & 88.50 & 80.25 & 0.73 \\
\hline $100 \%$ Pentonite & 13.75 & 0.694 & 71.25 & 59.25 & 0.89 \\
\hline $\begin{array}{l}\text { 25\% pent: } 75 \% \\
\text { lime }\end{array}$ & 19.25 & 0.949 & 64.75 & 58.00 & 0.78 \\
\hline $\begin{array}{l}50 \% \text { pent: } 50 \% \\
\text { lime }\end{array}$ & 18.25 & 1.082 & 66.00 & 57.25 & 0.84 \\
\hline $\begin{array}{l}75 \% \text { pent.: } 25 \% \\
\text { lime }\end{array}$ & 17.00 & 1.192 & 55.50 & 51.75 & 0.77 \\
\hline $100 \%$ lime & 16.00 & 1.054 & 66.50 & 56.25 & 0.83 \\
\hline LSD at $50 \%$ & N.S & 0.106 & 14.09 & 6.64 & 0.07 \\
\hline
\end{tabular}

Effect of pelleting process on seed quality

Since the biological parameters are considered as the major target for maintain high seed quality during and after pelleting process, data were subjected to backward multiple regression analysis for physical and mechanical parameters versus biological parameters under investigation (Table 13). It was found that geometric diameter, pellet weight, angle of repose and coefficient friction show no significant relation with germination \%, 
whereas, all physical and mechanical parameters contribute with a percentage of $69 \%$ on germination \%. As the four non-significant parameters previously mentioned eliminated, they had an effect with $2 \%$ only, while parameters of true density, sphericity, volume, intermediate diameter major diameter and minor diameter showed a contribution percentages of $4 \%, 6 \%$, $9 \%, 3 \%, 7 \%$ and $38 \%$, respectively, meaning that parameters of pellet axial dimensions and pellet volume and sphericity are the major variables had a remarkable relation with germination. Results of backward multiple regressions for physical and mechanical variables with vigor \% showed similar attitude. Whereas, geometric diameter, angle of repose and coefficient friction showed no significant relation on vigor \%. The most effective variables related to vigor $\%$ were true density, pellet weight, sphericity $\%$, pellet volume, intermediate diameters minor diameter and major diameter with percentages of $2 \%, 2 \%, 3 \%, 5 \%, 4 \%, 24 \%$ and $41 \%$, respectively.

Data in Table (13) show that intermediate diameter, geometric diameter, pellet weight, true density, angle of repose and coefficient of friction had no significant relation with germination rate. As these variables eliminated, it was found that their contribution a percentage of $3 \%$ only. On the other hand, angle of repose, minor diameter, pellet volume and major diameter show the greatest related variables with germination rate with a percentage of $2 \%, 19 \%, 3 \%$ and $14 \%$ respectively. It could be concluded that pellet seed axial dimensions, pellet volume and pellet sphericity $\%$ are the variables significantly related to biological parameters.

Multiple regression analysis was performed for relation of some physical and mechanical variables with biological properties (Germination \%, Vigor \% and germination rate) for the studied parameters affecting pelleting process (Table 14), whereas, results reveal that germination percentages were related with intermediate diameter minor diameter and geometric diameter as affected by rotational pan seed (rpm) parameters, major, intermediate and minor diameter as affected by seed quantity/ run parameters, major, minor, geometric diameters and pellet volume as affected by adhesive concentration parameters, major, intermediate, minor, diameters and pellet volume as affected by quantity of adhesive solution and ratio of pelleting material : seeds parameters and minor diameter as affected by ratio of pent.: lime parameters. It could be concluded that pellet dimensions and volume as physical variables were related and affect germination percentages when each investigated parameter was considered. Similar results were observed when multiple regression analysis was performed for relation of some physical and mechanical variables with vigor \%, therefore, the most physical properties related to vigor \% were pellet dimensions and volume.

Germination rate was related to pellet dimensions, pellet geometric diameter and sphericity \% as affected by rotational pan seed parameters. Seed quantity / run and adhesive concentration parameters affect the relation between major diameter and minor diameter with germination rate. 
J. Agric. Sci. Mansoura Univ., 33 (4), April, 2008

F 2 
EI-Nono, M. A. et al.

3 
J. Agric. Sci. Mansoura Univ., 33 (4), April, 2008

4

2431 
EI-Nono, M. A. et al.

Meanwhile, quantities of adhesive solution affect the relation between major diameter and sphericity \% characters. Ratio of pelleting material: seeds parameters show significant effect on the relation between germination rate and major diameter, sphericity \%, true density and angle of repose variables. Ratio of Pentonite: Lime in pelleting material show significant effect on the relation between germination rate and minor diameter.

Importance and significance of all investigation variables on the relation between physical and mechanical properties with biological investigated properties under each studied factor during eliminating each variable were presented in Table (14).

Table 13. Backward multiple regression analysis (overall studied factors) for germination and vigor percentages and germination rate

\begin{tabular}{|c|c|c|c|c|c|c|c|c|c|c|c|c|}
\hline \multirow{2}{*}{ Step. } & \multicolumn{12}{|c|}{ I. Germination percentage } \\
\hline & Const. & $\pm \mathrm{bv}_{1}$ & $\pm \mathrm{bv}_{2}$ & $\pm \mathrm{bv}_{3}$ & $\pm \mathrm{bv}_{4}$ & $\pm \mathrm{bv}_{5}$ & $\pm \mathrm{bv}_{6}$ & $\pm \mathrm{bV}_{7}$ & $\pm \mathrm{bv}_{8}$ & $\pm \mathrm{bv}_{9}$ & $\pm b v_{10}$ & $R^{2}(\%)$ \\
\hline Step 0 & 193.1 & $-11.3^{*}$ & $-1.3^{*}$ & $8.6^{*}$ & $-1.2 n s$ & $0.60^{*}$ & $-1.2^{*}$ & $5.4 \mathrm{~ns}$ & $-1.5^{\star}$ & $-0.4 n s$ & $-0.1 \mathrm{~ns}$ & 69 \\
\hline 1 & 196.5 & $-12.1^{*}$ & $-2.1^{*}$ & $9.3^{*}$ & $-1.1 \mathrm{~ns}$ & $0.6^{*}$ & $-1.3^{*}$ & $6.5 \mathrm{~ns}$ & $-1.5^{\star}$ & $-0.4 n s$ & $\mathrm{E}$ & 69 \\
\hline 2 & 198.2 & $-12.4^{*}$ & $-2.1^{*}$ & $9.4^{*}$ & $-0.2 n s$ & $0.6^{*}$ & $-1.3^{*}$ & E & $-1.3^{*}$ & $-0.4^{*}$ & $E$ & 68 \\
\hline 3 & 198.3 & $-12.4^{*}$ & $-2.2^{*}$ & $9.3^{*}$ & $E$ & $0.6^{*}$ & $-1.3^{*}$ & $E$ & $-1.3^{*}$ & $-0.4^{*}$ & $E$ & 68 \\
\hline 4 & 185.3 & $-11.1^{*}$ & $-3.8^{*}$ & $8.1^{*}$ & $E$ & $0.7^{\star}$ & $-1.2^{*}$ & $E$ & $-1.3^{*}$ & $E$ & $E$ & 67 \\
\hline 5 & 201.9 & $-13.4^{*}$ & $-0.3^{*}$ & $8.4^{*}$ & $E$ & $0.8^{*}$ & $-1.5^{\star}$ & $E$ & $E$ & $E$ & $E$ & 63 \\
\hline 6 & 145.3 & $-5.7^{\star}$ & $-21.0^{*}$ & $-10.1^{*}$ & $E$ & $1.7^{*}$ & $E$ & $E$ & $E$ & $E$ & $E$ & 57 \\
\hline 7 & 61.3 & $4.7^{*}$ & $12.2^{\star}$ & $-19.5^{*}$ & $E$ & $E$ & $E$ & $E$ & $E$ & $E$ & $E$ & 48 \\
\hline 8 & 59.7 & $10.3^{*}$ & $E$ & $-13.1^{*}$ & $E$ & E & $E$ & $E$ & E & $E$ & $E$ & 45 \\
\hline \multirow[t]{2}{*}{9} & 89.1 & $E$ & $E$ & $-7.0^{*}$ & $E$ & $E$ & $\mathrm{E}$ & $E$ & $E$ & $E$ & $E$ & 38 \\
\hline & \multicolumn{12}{|c|}{ II. Vigour percentage } \\
\hline Step 0 & 138.3 & $-8.9^{*}$ & $-1.4^{*}$ & $-1.0^{*}$ & $2.8 \mathrm{~ns}$ & $0.4^{*}$ & $-0.6^{*}$ & $-7.1^{*}$ & $-1.0^{*}$ & $0.2 \mathrm{~ns}$ & $-0.1 \mathrm{~ns}$ & 83 \\
\hline 1 & 136.8 & $-8.1^{*}$ & $-0.1^{*}$ & $0.02^{*}$ & E & $0.4^{*}$ & $-0.6^{*}$ & $-7.4^{*}$ & $-0.9^{*}$ & $0.2 \mathrm{~ns}$ & $-0.1 \mathrm{~ns}$ & 82 \\
\hline 2 & 144.3 & $-8.9^{*}$ & $0.7^{*}$ & $0.7^{*}$ & $E$ & $0.4^{*}$ & $-0.7^{*}$ & $-8.7^{*}$ & $-0.9^{*}$ & $E$ & $-0.1 \mathrm{~ns}$ & 82 \\
\hline 3 & 147.5 & $-9.4^{*}$ & $0.3^{*}$ & $2.0^{*}$ & $E$ & $0.4^{*}$ & $-0.8^{*}$ & $-7.5^{\star}$ & $-0.9^{*}$ & $E$ & E & 81 \\
\hline 4 & 158.5 & $-11.2^{*}$ & $1.9^{*}$ & $2.2^{*}$ & E & $0.5^{\star}$ & $-1.0^{*}$ & $-20.5^{\star}$ & $E$ & $E$ & $E$ & 79 \\
\hline 5 & 159.9 & $-11.1^{*}$ & $3.2^{*}$ & $2.1^{*}$ & $E$ & $0.4^{*}$ & $-1.0^{*}$ & $E$ & E & E & $E$ & 77 \\
\hline 6 & 121.4 & $-5.9^{\star}$ & $-10.8^{*}$ & $-10.5^{\star}$ & $E$ & $1.1^{*}$ & $E$ & $E$ & E & $E$ & $E$ & 74 \\
\hline 7 & 67.7 & $0.8^{*}$ & $10.5^{*}$ & $-16.5^{\star}$ & $E$ & $E$ & $E$ & $E$ & $E$ & $E$ & $E$ & 69 \\
\hline 8 & 66.3 & $5.6^{*}$ & $E$ & $-11.0^{*}$ & $E$ & $E$ & $E$ & $E$ & E & $E$ & $E$ & 65 \\
\hline \multirow[t]{2}{*}{9} & 104.1 & $-9.4^{*}$ & $E$ & $\mathrm{E}$ & $E$ & $E$ & $E$ & $E$ & $E$ & $E$ & $E$ & 41 \\
\hline & \multicolumn{12}{|c|}{ Germination rate } \\
\hline Step 0 & 0.30 & $0.11^{*}$ & $-0.14 n s$ & $0.01^{*}$ & $0.04 \mathrm{~ns}$ & $-0.002 n s$ & $0.01^{*}$ & $-0.03 n s$ & $8.3 n s$ & $-0.003 n s$ & $2.82 \mathrm{~ns}$ & 41 \\
\hline 1 & 0.29 & $0.11^{*}$ & $-0.14 n s$ & $0.01^{*}$ & $0.04 \mathrm{~ns}$ & $-0.002^{*}$ & $0.01^{*}$ & $E$ & $1.73 \mathrm{~ns}$ & $-0.003 n s$ & $3.02 \mathrm{~ns}$ & 41 \\
\hline 2 & 0.29 & $0.11^{*}$ & $-0.14 n s$ & $0.01^{*}$ & $0.04 \mathrm{~ns}$ & $-0.002^{*}$ & $0.01^{*}$ & $E$ & $E$ & $-0.003 n s$ & $3.02 \mathrm{~ns}$ & 41 \\
\hline 3 & 0.27 & $0.11^{*}$ & $-0.14 n s$ & $0.003^{*}$ & $0.04 \mathrm{~ns}$ & $-0.002^{*}$ & $0.01^{*}$ & $E$ & $E$ & $-0.003 n s$ & $E$ & 41 \\
\hline 4 & 0.23 & $0.11^{*}$ & $E$ & $0.014^{*}$ & $0.02 \mathrm{~ns}$ & $-0.007^{\star}$ & $0.004 \mathrm{~ns}$ & $E$ & $E$ & $-0.003 n s$ & $E$ & 39 \\
\hline 5 & 0.22 & $0.11^{*}$ & $E$ & $0.02^{*}$ & $E$ & $-0.007^{\star}$ & $0.004 \mathrm{~ns}$ & $E$ & $E$ & $-0.003 n s$ & $E$ & 39 \\
\hline 6 & 0.49 & $0.09^{*}$ & $E$ & $0.09^{*}$ & $E$ & $-0.007^{\star}$ & $E$ & $E$ & $E$ & $-0.004^{*}$ & $E$ & 38 \\
\hline 7 & 0.40 & $0.09^{*}$ & $E$ & $0.10^{*}$ & $E$ & $-0.008^{*}$ & $E$ & $E$ & $E$ & E & $E$ & 36 \\
\hline 8 & 0.40 & $0.12^{*}$ & $E$ & E & $E$ & $-0.003 n s$ & $E$ & $E$ & E & $E$ & $E$ & 17 \\
\hline 9 & 0.62 & $0.05^{*}$ & $E$ & $E$ & $E$ & $E$ & $E$ & E & $E$ & $E$ & $E$ & 14 \\
\hline
\end{tabular}

E: Eliminated variable

b: Slop

$\mathbf{v}_{1}-\mathbf{v}_{10}$ : Variable arranged respectively as follow (major dia, intermediate dia., minor dia., geometric dia, volume, sphericity, weigh, true density, angle of repose and coefficient friction

*: Significant values, ns : Non-significant values 
J. Agric. Sci. Mansoura Univ., 33 (4), April, 2008

Table 14. Multiple regression analysis of physical and mechanical variables for biological properties of sesame pelleted seeds.

\begin{tabular}{|c|c|c|c|c|c|c|c|c|c|c|c|c|c|c|c|}
\hline \multicolumn{2}{|c|}{ step constant } & $b^{*} V 1$ & & $b^{*} \mathrm{~V} 2$ & & $b^{*} V 3$ & & $b^{*} V_{4}$ & $b^{*} \mathrm{~V} 5$ & $b^{*} V 6$ & $b^{*} V 7$ & $b^{*} V 8$ & $b^{*} \mathrm{~V} 9$ & $b^{*} V 10$ & $\mathrm{R}^{2} \%$ \\
\hline & & \multicolumn{14}{|c|}{$\begin{array}{c}\text { A. Rotational speed of pelleting pan } \\
\text { 1. Germination \% } \\
\end{array}$} \\
\hline 0 & 25.17 & 116.72 & & 104.34 & ** & 171.58 & * & -359.67 & -0.98 & -0.56 & 210.73 & 1.90 & -0.76 & 0.11 & 87.7 \\
\hline 1 & 23.42 & 114.43 & & 104.41 & ** & 167.91 & * & -348.63 & -1.28 & -0.64 & 260.95 & & -0.78 & 0.09 & 87.6 \\
\hline 2 & 27.08 & 112.66 & & 102.20 & ** & 165.25 & * & -345.68 & -1.07 & -0.53 & 235.98 & * & -0.79 & & 87.3 \\
\hline 3 & -1.14 & 123.57 & & 100.29 & ** & 169.16 & ** & -367.24 & -0.78 & & 245.23 & * & -0.79 & & 87.2 \\
\hline 4 & 32.64 & 107.67 & & 80.83 & $* *$ & 151.09 & $* *$ & -328.83 & $* *$ & & 213.37 & ** & -0.75 & & 86.9 \\
\hline 5 & 49.09 & & & -13.15 & * & -47.71 & ** & 53.76 & & & 241.83 & & 0.29 & & 56.7 \\
\hline 6 & 55.10 & & & -12.90 & * & -46.22 & ** & 51.89 & & & 243.72 & & & & 56.0 \\
\hline 7 & 70.12 & & & 17.20 & * & -23.41 & * & & & & 189.00 & & & & 50.0 \\
\hline 8 & 62.94 & & & 18.31 & * & -19.31 & * & & & & & & & & 41.8 \\
\hline \multirow[t]{2}{*}{9} & 86.87 & & & & & -5.84 & * & & & & & & & & 28.2 \\
\hline & & \multicolumn{14}{|c|}{ 2. Vigor $\%$} \\
\hline 0 & -32.53 & 81.86 & ** & 30.54 & ** & 78.36 & $*$ & -211.43 & 0.65 & 1.51 & 215.90 & -4.01 & 0.34 & -0.17 & 92.0 \\
\hline 1 & -28.82 & 86.70 & ** & 30.39 & ** & 86.12 & * & -234.79 & 1.28 & 1.67 & 109.66 & & 0.39 & -0.13 & 91.7 \\
\hline 2 & 58.33 & 53.09 & ** & 36.71 & ** & 74.43 & * & -168.22 & 0.35 & & 85.24 & & 0.38 & -0.11 & 90.5 \\
\hline 3 & 46.65 & 58.04 & ** & 38.97 & ** & 78.71 & * & -177.34 & 0.17 & & 118.51 & & 0.39 & & 89.8 \\
\hline 4 & 43.72 & 70.58 & ** & 51.47 & ** & 100.79 & * & -219.63 & -0.01 & & 125.61 & & & & 88.4 \\
\hline 5 & 44.32 & 70.31 & ** & 51.14 & ** & 100.50 & * & -219.00 & ** & & 125.05 & * & & & 88.4 \\
\hline 6 & 42.64 & 72.80 & ** & 60.86 & ** & 112.64 & * & -239.61 & $* *$ & & & & & & 83.9 \\
\hline 7 & 54.85 & 14.59 & ** & 3.15 & ** & -19.88 & & & & & & & & & 66.2 \\
\hline 8 & 59.30 & 15.05 & ** & -18.92 & ** & & & & & & & & & & 58.1 \\
\hline \multirow[t]{2}{*}{9} & 89.02 & & & -8.03 & ** & & & & & & & & & & 44.8 \\
\hline & & \multicolumn{14}{|c|}{ 3. Germination rate } \\
\hline 0 & -0.10 & -0.06 & ** & -1.08 & * & -0.89 & * & 0.93 & 0.05 & $0.03 *$ & -5.43 & 0.19 & 0.00 & $0.00 *$ & 90.3 \\
\hline 1 & -0.12 & -0.01 & ** & -1.01 & * & -0.79 & * & 0.77 & 0.05 & $0.03 *$ & -5.06 & 0.18 & & 0.00 * & 89.8 \\
\hline 2 & -0.11 & -0.17 & ** & -0.52 & & -0.79 & & 1.39 & ** & 0.01 & -1.63 & 0.07 & & 0.00 & 82.2 \\
\hline 3 & -0.21 & -0.29 & ** & -0.73 & & -1.08 & & 1.95 & ** & 0.01 & 0.00 & & & 0.00 & 80.5 \\
\hline 4 & -0.21 & -0.29 & ** & -0.73 & & -1.08 & & 1.95 & ** & 0.01 & & & & 0.00 & 80.5 \\
\hline 5 & -0.50 & -0.18 & ** & -0.67 & & -1.04 & & 1.72 & ** & 0.02 & & & & & 76.9 \\
\hline 6 & 0.93 & -0.77 & ** & -0.91 & & -1.46 & & 3.05 & ** & & & & & & 72.6 \\
\hline 7 & 0.77 & -0.01 & * & -0.16 & & & & 0.21 & & & & & & & 40.0 \\
\hline 8 & 0.79 & -0.04 & * & & & & & 0.09 & & & & & & & 36.0 \\
\hline \multirow[t]{2}{*}{9} & 0.57 & 0.07 & * & & & & & & & & & & & & 23.8 \\
\hline & & \multicolumn{14}{|c|}{$\begin{array}{l}\text { B. Seed quantity / run } \\
\text { 1. Germination } \%\end{array}$} \\
\hline 0 & 169.86 & -22.20 & $"$ & -32.85 & $"$ & -34.32 & $"$ & 54.44 & 1.11 & -0.02 & 94.23 & -2.36 & -0.42 & -0.21 & 89.1 \\
\hline 1 & 170.33 & -22.45 & " & -33.44 & • & -34.55 & . & 54.84 & 1.13 & & 92.88 & -2.35 & -0.42 & -0.21 & 89.1 \\
\hline 2 & 172.89 & -23.89 & " & -29.92 & • & -33.94 & $*$ & 50.46 & 1.37 & & & -0.58 & -0.19 & -0.30 & 88.7 \\
\hline 3 & 165.99 & -23.28 & $*$ & -29.61 & $*$ & -37.81 & $"$ & 53.76 & 1.37 & & & & -0.09 & -0.31 & 88.6 \\
\hline 4 & 162.92 & -22.67 & $"$ & -29.12 & $"$ & -37.63 & $"$ & 53.23 & 1.34 & & & & & -0.32 & 88.5 \\
\hline 5 & 178.33 & -28.52 & " & -42.46 & $*$ & -39.72 & $"$ & 64.44 & 1.66 & & & & & & 86.3 \\
\hline 6 & 117.45 & -4.23 & " & -4.09 & $\cdot$ & -12.93 & " & & 0.69 & & & & & & 77.8 \\
\hline 7 & 75.13 & 2.01 & " & 11.24 & • & -19.10 & $"$ & & & & & & & & 76.6 \\
\hline 8 & 78.46 & 5.28 & * & & & -11.56 & $"$ & & & & & & & & 72.5 \\
\hline \multirow[t]{2}{*}{9} & 114.87 & -9.97 & “ & & & & & & & & & & & & 40.2 \\
\hline & & \multicolumn{14}{|c|}{ 2. Vigor $\%$} \\
\hline 0 & 55.53 & 10.85 & " & 19.24 & " & -0.12 & $"$ & -12.96 & -0.86 & -0.64 & 131.21 & -2.78 & 0.72 & -0.01 & 96.6 \\
\hline 1 & 55.70 & 10.84 & $"$ & 19.14 & * & -0.09 & $"$ & -12.85 & -0.86 & -0.65 & 133.05 & -2.81 & 0.71 & & 96.6 \\
\hline 2 & 65.80 & 5.57 & " & 7.69 & $"$ & -6.79 & $"$ & & -0.49 & -0.46 & 126.90 & -2.75 & 0.78 & & 96.4 \\
\hline 3 & 81.67 & -0.58 & 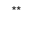 & 2.75 & $*$ & -7.49 & $"$ & & 0.14 & -0.31 & & -0.65 & 0.99 & & 95.2 \\
\hline 4 & 75.53 & 0.57 & * & 6.03 & $*$ & -8.28 & $"$ & & & -0.37 & & -0.52 & 1.00 & & 95.2 \\
\hline 5 & 74.15 & 1.26 & " & 7.04 & $"$ & -9.08 & $"$ & & & -0.43 & & & 1.05 & & 95.0 \\
\hline 6 & 42.64 & 4.65 & ” & 6.57 & " & -15.75 & $"$ & & & & & & 1.26 & & 93.1 \\
\hline 7 & 65.57 & 1.34 & " & 12.18 & " & -18.34 & $"$ & & & & & & & & 84.6 \\
\hline 8 & 69.18 & 4.89 & $"$ & & & -10.17 & $"$ & & & & & & & & 77.8 \\
\hline 9 & 101.22 & -8.53 & 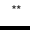 & & & & & & & & & & & & 42.1 \\
\hline
\end{tabular}


EI-Nono, M. A. et al.

Table 14 Cont.

\begin{tabular}{|c|c|c|c|c|c|c|c|c|c|c|c|c|c|c|c|c|}
\hline \multicolumn{2}{|c|}{ step constant } & $b^{*} \mathrm{~V} 1$ & & $b * V 2$ & & $b^{*} V 3$ & & $\mathrm{~b}^{*} \mathrm{~V} 4$ & $b^{*} \mathrm{~V} 5$ & & $b^{*} V 6$ & $b^{*} \mathrm{V7}$ & $b^{*} V 8$ & $b^{*} V 9$ & $b^{*} V 10$ & $\mathrm{R}^{2} \%$ \\
\hline & & \multicolumn{15}{|c|}{ 3. Germination rate } \\
\hline 0 & 1.36 & -0.11 & ' & -0.47 & & 0.15 & * & 0.15 & 0.01 & & 0.00 & -1.29 & 0.02 & -0.01 & 0.00 & 82.0 \\
\hline 1 & 1.29 & -0.13 & ' & -0.50 & & 0.11 & * & 0.17 & 0.02 & & 0.01 & -1.95 & 0.03 & & 0.00 & 81.3 \\
\hline 2 & 0.67 & 0.06 & * & -0.12 & & 0.19 & - & -0.06 & & & 0.00 & -1.15 & 0.03 & & 0.00 & 78.7 \\
\hline 3 & 0.66 & 0.06 & " & -0.15 & & 0.16 & " & & & & 0.00 & -0.99 & 0.02 & & 0.00 & 78.6 \\
\hline 4 & 0.60 & 0.04 & " & & & 0.09 & & & & & 0.00 & -2.05 & 0.05 & - & 0.00 & 75.9 \\
\hline 5 & 0.59 & 0.04 & " & & & 0.08 & & & & & 0.00 & -2.02 & 0.05 & " & & 75.4 \\
\hline 6 & 0.51 & 0.05 & " & & & 0.06 & * & & & & & -2.02 & 0.04 & & & 75.1 \\
\hline 7 & 0.52 & 0.06 & " & & & 0.00 & & & & & & & 0.02 & & & 56.4 \\
\hline 8 & 0.71 & 0.00 & ' & & & 0.05 & & & & & & & & & & 47.9 \\
\hline \multirow[t]{2}{*}{9} & 0.54 & 0.07 & . & & & & & & & & & & & & & 36.2 \\
\hline & & \multicolumn{15}{|c|}{$\begin{array}{c}\text { C. Adhesive concentration } \\
\text { 1. Germination } \%\end{array}$} \\
\hline 0 & 238.77 & -26.35 & * & -87.83 & & -15.42 & & 63.45 & 2.94 & * & -0.03 & 49.83 & -3.86 & 0.35 & -0.28 & 89.1 \\
\hline 1 & 218.70 & -22.23 & ** & -76.65 & & -13.21 & & 49.08 & 2.78 & ** & 0.13 & 23.89 & -3.80 & & -0.11 & 88.9 \\
\hline 2 & 210.63 & -21.67 & ** & -73.63 & & -13.23 & * & 45.21 & 2.82 & ** & 0.19 & 0.40 & -3.43 & & & 88.9 \\
\hline 3 & 210.62 & -21.68 & ** & -73.61 & & -13.23 & * & 45.19 & 2.82 & ** & 0.19 & & -3.43 & & & 88.9 \\
\hline 4 & 252.86 & -16.58 & ** & & & 26.40 & * & -27.84 & 1.53 & ** & -1.71 & & -0.46 & & & 85.4 \\
\hline 5 & 262.51 & -16.69 & ** & & & 28.35 & * & -30.12 & 1.64 & ** & $-1.86 \times$ & & & & & 85.3 \\
\hline 6 & 286.46 & -29.42 & ** & & & 17.74 & * & & 1.39 & ** & $-2.31 *$ & & & & & 84.0 \\
\hline 7 & 219.67 & -18.87 & ** & & & & & & 1.54 & ** & $-1.46 *$ & & & & & 79.9 \\
\hline 8 & 97.68 & 18.11 & ** & & & & & & & & $-1.43 *$ & & & & & 62.1 \\
\hline \multirow[t]{2}{*}{9} & 119.40 & -11.12 & * & & & & & & & & & & & & & 31.3 \\
\hline & & \multicolumn{15}{|c|}{ 2. Vigor $\%$} \\
\hline 0 & 68.88 & 1.62 & ** & -3.14 & & 1.15 & * & -23.63 & 0.30 & & 0.79 & 114.71 & -5.03 & -0.18 & 0.41 & 95.6 \\
\hline 1 & 67.32 & 2.15 & ** & & & 2.32 & * & -27.13 & 0.26 & ** & 0.76 & 109.35 & -4.90 & -0.21 & 0.43 & 95.5 \\
\hline 2 & 80.04 & 0.20 & ** & & & 4.05 & * & -25.45 & 0.28 & ** & 0.54 & 115.36 & -4.55 & ** & 0.37 & 95.4 \\
\hline 3 & 51.10 & 0.15 & ** & & & -1.49 & * & -28.23 & 0.67 & ** & 1.04 & & -3.29 & * & $0.65 *$ & 94.6 \\
\hline 4 & 116.41 & -9.54 & ** & & & 3.84 & * & -15.54 & 0.70 & ** & & & -2.27 & * & 0.49 & 92.3 \\
\hline 5 & 114.42 & -14.87 & ** & & & -3.74 & * & & 0.49 & ** & & & -2.68 & ** & 0.50 & 91.7 \\
\hline 6 & 132.52 & -15.67 & ** & & & -0.76 & * & & 0.32 & ** & & & -2.97 & ** & & 88.9 \\
\hline 7 & 134.44 & -16.37 & ** & & & & & & 0.30 & ** & & & -3.04 & ** & & 88.9 \\
\hline 8 & 110.24 & -8.82 & ** & & & & & & & & & & -3.26 & ** & & 88.1 \\
\hline \multirow[t]{2}{*}{9} & 115.42 & -11.88 & $* *$ & & & & & & & & & & & & & 53.6 \\
\hline & & \multicolumn{15}{|c|}{ 3. Germination rate } \\
\hline 0 & 0.94 & 0.13 & ** & -0.80 & & 0.09 & * & 0.38 & 0.01 & & 0.00 & 2.39 & -0.01 & 0.01 & 0.00 & 88.8 \\
\hline 1 & 0.87 & 0.19 & ** & -0.50 & & 0.21 & * & 0.14 & & & -0.01 & 2.65 & -0.01 & 0.01 & 0.00 & 87.0 \\
\hline 2 & 0.78 & 0.22 & ** & -0.41 & & 0.25 & ** & & & & -0.01 & 2.38 & 0.00 & 0.01 & 0.00 & 86.9 \\
\hline 3 & 0.56 & 0.22 & ** & -0.38 & & 0.20 & ** & & & & 0.00 & 1.99 & 0.00 & 0.01 & & 86.6 \\
\hline 4 & 0.59 & 0.21 & ** & -0.37 & & 0.21 & ** & & & & 0.00 & 1.93 & & 0.01 & & 86.6 \\
\hline 5 & 1.48 & -0.12 & * & & & 0.17 & & & & & -0.01 & 1.78 & & 0.00 & & 59.7 \\
\hline 6 & 0.94 & -0.08 & ** & & & 0.06 & & & & & & 0.92 & & 0.00 & & 56.5 \\
\hline 7 & 0.95 & -0.08 & ** & & & 0.06 & & & & & & 0.87 & & & & 56.2 \\
\hline 8 & 1.01 & -0.10 & ** & & & 0.11 & & & & & & & & & & 50.7 \\
\hline \multirow[t]{2}{*}{9} & 0.46 & 0.09 & ** & & & & & & & & & & & & & 39.3 \\
\hline & & \multicolumn{15}{|c|}{$\begin{array}{c}\text { D. Quantity of adhesive } \\
\text { 1. Germination } \%\end{array}$} \\
\hline 0 & 187.15 & -16.60 & ** & -26.20 & * & -2.33 & ** & 11.90 & 1.47 & * & -0.21 & -3.26 & -1.33 & -0.36 & -0.03 & 93.2 \\
\hline 1 & 198.98 & -18.66 & ** & -27.45 & * & -0.54 & ** & 13.13 & 1.54 & ** & -0.35 & -3.10 & -1.33 & -0.39 & & 93.1 \\
\hline 2 & 241.02 & -22.97 & ** & -17.31 & * & 10.78 & ** & & 1.71 & ** & -1.06 & -2.49 & -0.64 & -0.24 & & 92.4 \\
\hline 3 & 227.45 & -21.24 & ** & -20.54 & ** & 8.70 & ** & & 1.81 & ** & -0.84 & -1.29 & -0.66 & & & 92.2 \\
\hline 4 & 224.53 & -20.83 & ** & -19.41 & ** & 8.38 & ** & & 1.75 & ** & -0.85 & & -0.70 & & & 92.2 \\
\hline 5 & 265.18 & -26.42 & $* *$ & -9.64 & ** & 16.86 & ** & & 1.56 & ** & -1.75 & & & & & 89.6 \\
\hline 6 & 212.48 & -15.94 & ** & -45.41 & * & 0.34 & ** & & 2.91 & ** & & & & & & 84.0 \\
\hline 7 & 109.79 & -4.66 & $* *$ & & & -15.34 & ** & & 0.85 & & & & & & & 73.7 \\
\hline 8 & 54.73 & 12.55 & ** & & & -14.77 & ** & & & & & & & & & 66.2 \\
\hline 9 & 89.64 & & ** & & & -6.52 & ** & & & & & & & & & 53.1 \\
\hline
\end{tabular}


J. Agric. Sci. Mansoura Univ., 33 (4), April, 2008

Table 14. Cont.

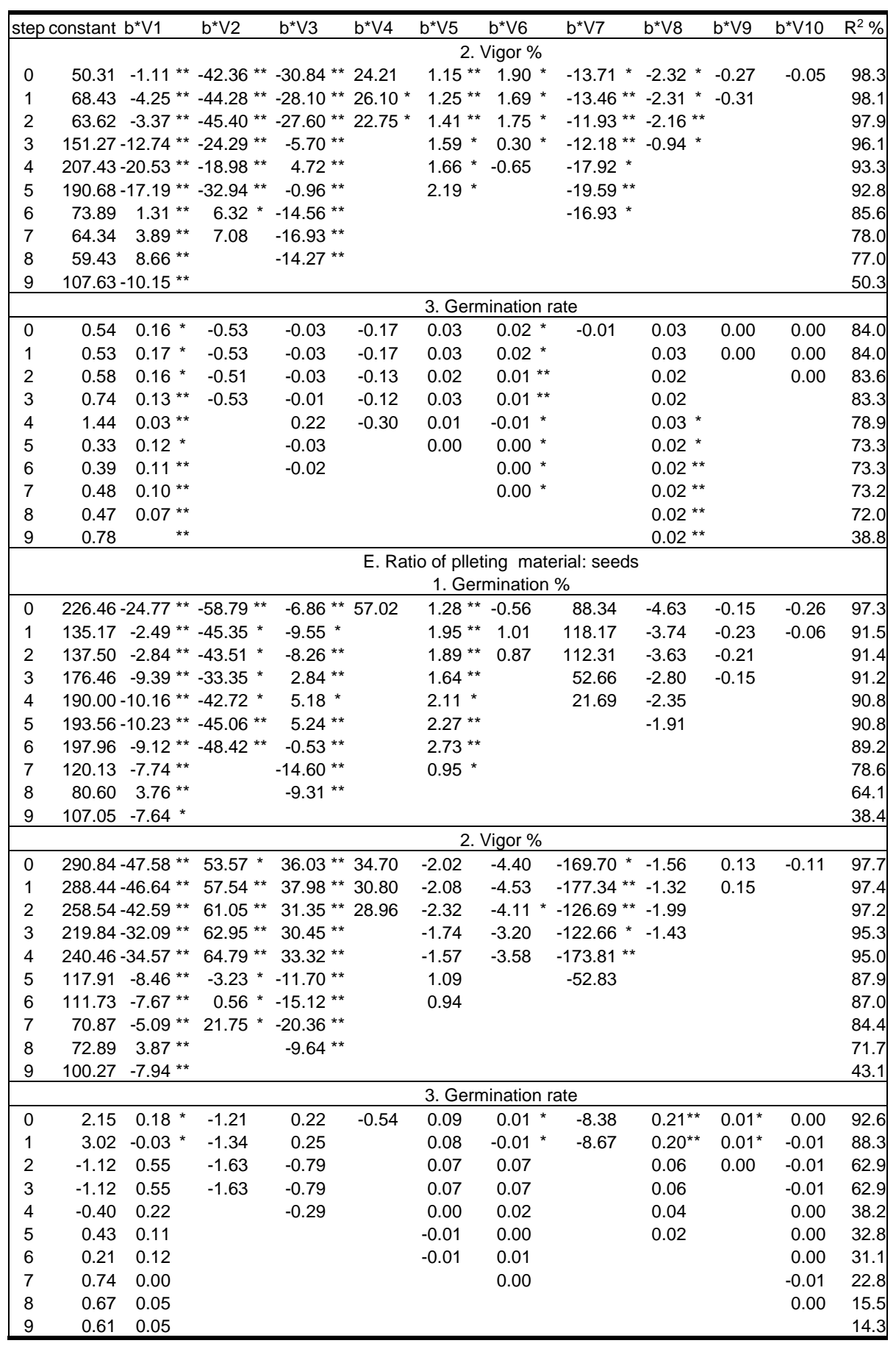


EI-Nono, M. A. et al.

Table 14. Cont.

\begin{tabular}{|c|c|c|c|c|c|c|c|c|c|c|c|c|}
\hline \multicolumn{2}{|c|}{ step constant } & $\mathrm{b}^{*} \mathrm{~V} 1$ & $\mathrm{~b}^{*} \mathrm{~V} 2$ & $b^{*} V_{3}$ & $b^{*} V 4$ & $b^{*} \mathrm{~V} 5$ & $\mathrm{~b}^{*} \mathrm{~V} 6$ & $\mathrm{~b}^{*} \mathrm{~V} 7$ & $b^{*} \mathrm{~V} 8$ & $\mathrm{~b}^{*} \mathrm{~V} 9$ & $b^{*} \mathrm{~V} 10$ & $\mathrm{R}^{2} \%$ \\
\hline & & \multicolumn{11}{|c|}{$\begin{array}{l}\text { F. Ratio of pent.: lime } \\
\text { 1. Germination \% }\end{array}$} \\
\hline 0 & 189.26 & -7.27 & 29.87 & -1.41 ** & -0.83 & -0.19 & -1.73 & 37.53 & -1.21 & -1.20 & -0.58 & 66.8 \\
\hline 1 & 122.27 & 0.32 & 7.36 & $-21.45^{* *}$ & -3.03 & 0.92 & & 1.31 & -1.10 & -0.96 & -0.45 & 65.5 \\
\hline 2 & 127.24 & -1.62 & 5.24 & -22.08 ** & & 0.99 & & 2.53 & -1.19 & -0.95 & -0.44 & 65.3 \\
\hline 3 & 135.11 & -4.72 & -4.66 & $-17.03^{* *}$ & & 1.37 & & -77.85 & -0.86 & -0.89 & & 63.5 \\
\hline 4 & 128.93 & -5.00 & 2.36 & $-22.11^{* *}$ & & 1.39 & & -111.61 & & -1.05 & & 63.0 \\
\hline 5 & 132.74 & -5.11 & & $-21.33^{* *}$ & & 1.47 * & & -109.98 & & -1.05 & & 63.0 \\
\hline 6 & 111.59 & -4.44 & & $-17.70^{* *}$ & & 1.18 * & & -125.00 & & & & 58.8 \\
\hline 7 & 104.17 & -0.33 & & $-28.52^{* *}$ & & 1.43 * & & & & & & 53.5 \\
\hline 8 & 103.15 & & & -28.59 ** & & 1.42 ** & & & & & & 53.5 \\
\hline \multirow[t]{2}{*}{9} & 73.38 & & & & & -0.18 & & & & & & 4.4 \\
\hline & & \multicolumn{11}{|c|}{ 2. Vigor $\%$} \\
\hline 0 & 75.97 & $1.67 * *$ & $9.21 *$ & $-17.93^{* *}$ & -0.75 & 0.35 & -0.12 & -94.40 & 0.47 & 0.05 & 0.01 & 87.9 \\
\hline 1 & 76.22 & $1.67 * *$ & $9.46 * *$ & $-17.88^{* *}$ & -0.75 & 0.34 & -0.13 & -93.17 & 0.46 & 0.05 & & 87.9 \\
\hline 2 & 77.82 & $1.50^{* *}$ & 10.18 ** & $-17.81 * *$ & -0.73 & 0.32 & -0.16 & -93.83 & 0.50 & & & 87.9 \\
\hline 3 & 71.35 & $2.31^{* *}$ & $8.52^{* *}$ & $-20.03^{* *}$ & -0.97 & 0.42 & & -95.33 & 0.51 & & & 87.9 \\
\hline 4 & 72.95 & $1.70^{* *}$ & 7.92 ** & -20.29 ** & & 0.44 & & $-94.75 *$ & 0.49 & & & 87.8 \\
\hline 5 & 78.05 & 1.81 ** & $4.11^{* *}$ & $-17.78^{* *}$ & & 0.45 & & $-74.29 *$ & & & & 87.4 \\
\hline 6 & 55.32 & 4.09 ** & $14.07^{* *}$ & -20.22 ** & & & & -86.45 & & & & 86.7 \\
\hline 7 & 40.31 & $8.96^{* *}$ & $16.13^{* *}$ & $-28.13^{* *}$ & & & & & & & & 81.9 \\
\hline 8 & 34.44 & 17.36 ** & & $-19.94^{* *}$ & & & & & & & & 76.4 \\
\hline \multirow[t]{2}{*}{9} & 101.94 & $-9.48^{* *}$ & & & & & & & & & & 39.2 \\
\hline & & \multicolumn{11}{|c|}{ 3. Germination rate } \\
\hline 0 & 1.42 & 0.02 & -0.22 & $0.41^{* *}$ & -0.04 & 0.00 & -0.01 & -0.60 & 0.01 & 0.00 & 0.00 & 73.7 \\
\hline 1 & 1.46 & 0.02 & -0.18 & $0.41^{* *}$ & -0.04 & -0.01 & -0.01 & -0.40 & 0.01 & 0.00 & & 73.4 \\
\hline 2 & 1.56 & 0.02 & -0.22 & $0.43^{* *}$ & -0.04 & 0.00 & -0.01 & & 0.00 & 0.00 & & 72.2 \\
\hline 3 & 1.56 & 0.02 & -0.24 & $0.45^{* *}$ & -0.03 & 0.00 & -0.01 & & & 0.00 & & 71.8 \\
\hline 4 & 1.48 & 0.03 & -0.34 & $0.40^{* *}$ & -0.03 & & -0.01 & & & 0.00 & & 71.0 \\
\hline 5 & 1.35 & 0.04 & -0.35 & 0.39 ** & -0.04 & & -0.01 & & & & & 69.8 \\
\hline 6 & 1.55 & & -0.34 & $0.43^{* *}$ & -0.03 & & -0.01 & & & & & 69.3 \\
\hline 7 & 0.62 & & & $0.02^{* *}$ & -0.06 & & 0.00 & & & & & 14.2 \\
\hline 8 & 0.84 & & & 0.08 & -0.07 & & & & & & & 10.7 \\
\hline 9 & 0.76 & & & & 0.01 & & & & & & & 2.5 \\
\hline
\end{tabular}

** $=$ highly significant,$*$ significant, unmarked values $=$ non significant and blank cells $=$ eliminated value, $\mathbf{b}=$ slope

$\mathrm{v}_{1}-\mathrm{v}_{10}$ : Variable arranged respectively as follow (major dia, intermediate dia., minor dia., geometric dia, volume, sphericity, weigh, true density, angle of repose and coefficient friction 


\section{SUMMARY AND CONCLUSION}

A machine for pelleting small and light sesame seeds was used to enlarge size and change shape to become more heavier and rounder to facilitate handling and planting through a mechanized application. Results of physical, mechanical and biological properties of sesame pelleted seeds as response of pelleting process factors could be summarized as follow:

1-Rotating pan speed of $30 \mathrm{rpm}$ showed the greatest pellet weight, sphericity percentage.

2- Using $250 \mathrm{~g}$ seeds/ run showed maximum pellet dimensions, pellet volume and weight.

3- Maximum pellet dimensions and maximum pellet sphericity were obtained when a ratio of pelleting material: seeds was 20:1

4-Adhesive material concentration (5\%) showed a maximum pellet size, volume and weight.

5- Quantity of $50 \mathrm{~mm}^{3}$ adhesive solution per $500 \mathrm{~g}$ pelleting material gave maximum pellet volume and weight.

6- Ratio of $75 \%$ Pentonite $+25 \%$ lime gave maximum pellet dimensions, volume and weight.

7- Germination rate increased when seeds were pelleted .

8- Biological properties were greatly related with pellet dimensions and volume.

\section{REFERENCES}

Abdel-Tawab, I.M. (2005). Modification and Fabrication of Coating Machine for Sugar Beet Seeds. Misr J. Ag. Eng., 22(1): 102-114.

Agricultural Statistics (2006). Summer and Nili Crops, Economic Affairs Sector. Vol. 2, p. 131. Ministry of Agriculture and Land Reclamation, Cairo, Egypt.

ASAE Standards (1996). Compression Test of Food Materials of Convex Shape : 558-563.

Barut, Z.B. and M.I. Cagrgan (2006). Effect of seed coating on the accuracy of single seed sowing of sesame under field conditions. Australian Journal of Experimental Agriculture, SIRO Publishing, Collingwood, Australia, 46: 71-76.

Chung, H.S. and W.B. Choi (1990). Biological control of sesame damping-off in the field by coating seed with antagonistic Trichoderma viride. Seed Science and Technology, 18: 2, 451-459.

Copeland, L.O. and M.B. McDonald (1995). Seed Enhancements. Seed Science and Technology, $3^{\text {rd }}$ Ed. pp. 258-276. Chapman \& Hall, New York, NY10001, USA.

Dogan, T.; E. Aykas; N.H. Tuvay and A. Zeybek (2005). A study on pelleting and planting sesame (Sesamum indicum L.) seeds. Asian Journal of Plant Science, ANSI net, Asian Network for Scientific Information, Faisalabad, Pakistan, 4: 5, 449-454.

Gomez K. A. and A. A. Gomez (1984). Statistical Procedures for Agricultural Research, Second Edition , John Wiley \& Sons - New York

Halmer, P. (2005). Chemical Loading and Dust Management. $2^{\text {nd }}$ Seed Treatment Conference, p. 12. Santiago de Chile. 
ISTA (1996). International Rules for Seed Testing Association. Seed Science and Technology 24, Supplement: 29-34.

Mohsenin, N.N. (1986). Physical Properties of Plant and Animal Materials. Vol. 1. Gordon and Breach Sc. Pub., Inc. New York: 58-60.

Pineda, J.B. (2001). Evaluation of Trichoderma harzianum application methods to the soil for control of Macrophomina phaseolina in Sesame. Fitopathologia Venezolana. Socieded Venezolana de Fitopatologia, Maracy, Venezuela, 14: 2, 31-34.

Ryv, C.; J. Kim; O. Choi; S. Kim and C. Park (2006). Improvement of biological control capacity of Paenibacillus polymyxa E681 by seed pelleting on sesame. Biological Control. Elsevier, Amsterdam, Netherlands, 39: 3, 282-289.

Sahhar, E.A.; A.A. Abdel-Aziz and M.A. El-Nono (2006). Operating considerations for small rotating drum for sesame seeds coating. Annals Agric. Sci., Ain Shams Univ., Cairo, 51(1): 59-82.

SAS (1988). SAS Procedures Guide, Release 6.03 Edition, SAS Institute Inc., Carry, NC.

Scott, J.M.; G.J.Blair and H.C.Andrews (1997). The mechanics\&coating seeds in a small rotating drum. Seed Science \& Technology,25:281-292.

Shewmaker, G.E.; M.H. Hopwood and R.L. Roemer (2002). Implications of seeding rates and seed coating with improved alfalfa varieties. Proceedings of the Western Alfalfa and Forage Conference, pp. 525531. Reno, NV, LIC Cooperative Extension, Univ. of California, Davis.

Tilcher, R. (2005). Equipment Batch Treaters, Continuous Flow and Coatings. $2^{\text {nd }}$ Seed Treatment Conference, P. 10. Santiago de Chile.

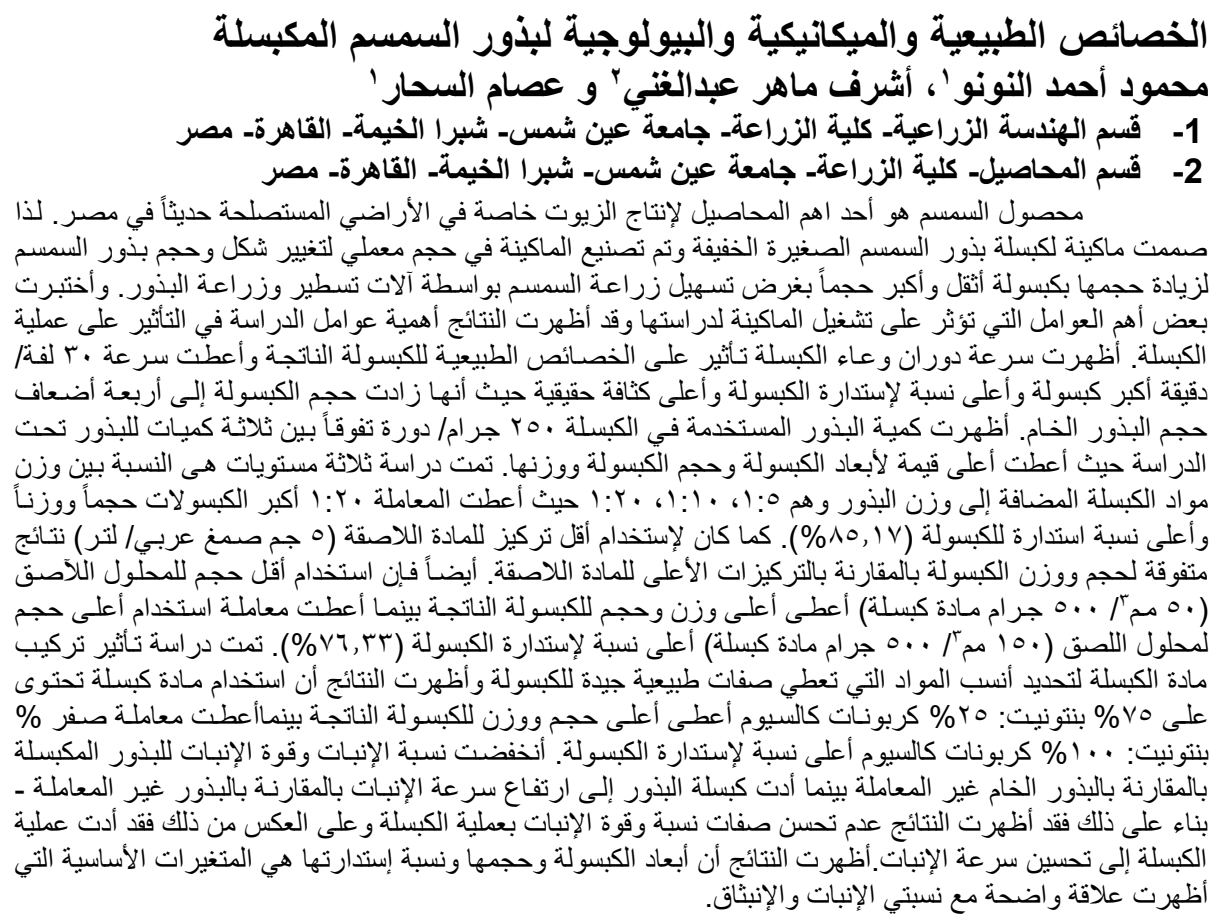

